\title{
NEURONAL APOPTOSIS AND INTERVENTION STRATEGIES
}

\author{
Nota del m.s. GIORGIO TERENGHI (*)
}

(Adunanza del 23 ottobre 2014)

SunTo. - A seguito di una lesione distale di un nervo periferico, si riscontra la morte di una proporzione delle cellule neuronali sensoriali nei gangli dorsali. Se il trauma è più prossimale, per esempio una lesione del plesso brachiale, anche una proporzione dei corrispondenti neuroni motori muore. Questo fenomeno è stato poco studiato, ma è importante perchè le cellule neuronali perse non possono essere sostituite per la mancata potenzialità di divisione cellulare, con conseguente rigenerazione sub-optimale e deficit di recupero sensoriale del paziente. Ultimamente è stato accertato che la morte neuronale è dovuta al processo di apoptosi, come rivelato da studi di geni specifici che regolano i segnali apoptotici. Un intervento di riparazione chirurgica immediata del nervo conferisce una minima neuro-protezione, ma non abolisce completamente la morte cellulare dei neuroni, soprattutto questo approccio non è sempre possibile. I nostri studi hanno dimostrato che un intervento farmacologico usando sia acetil-L-carnitina (ALCAR) che N-acetil-cisteina (NAC) produce una protezione totale dei neuroni a seguito di lesioni dei nervi. Entrambi ALCAR e NAC sono già in uso clinico per altre applicazioni, ed i nostri studi hanno stabilito la miglior dose e la durata di somministrazione. L'efficacia della neuroprotezione di ALCAR e NAC può essere monitorata tramite risonanza magnetica del volume dei gangli dorsali, come dimostrato sia sperimentalmente che clinicamente. L'applicazione farmacologica sui pazienti richiede ulteriori studi, ma i risultati ottenuti finora dimostrano che questo approccio potrà determinare la sopravvivenza dei neuroni ed un miglioramento della rigenerazione dei nervi.

(*) Professore di Ingegneria Tissutale, Centre for Tissue Injury \& Repair University of Manchester.

E-mail: giorgio.terenghi@manchester.ac.uk 
$* * *$

ABSTRACT. - Following distal nerve injury significant sensory neuronal cell death occurs in the dorsal root ganglia, while after a more proximal injury, such as brachial plexus injury, a sizeable proportion of spinal motoneurons also undergo cell death. This phenomenon has been undervalued for a long time, but it has a significant role in the lack of functional recuperation, as neuronal cells cannot divide and be replaced, hence the resulting nerve regeneration is usually suboptimal. It is now accepted that this cell death is due to apoptosis, as indicated by analysis of specific genes involved in the apoptotic signalling cascade. Immediate nerve repair, either by direct suturing or nerve grafting, gives a degree of neuroprotection, but this approach does not fully prevent neuronal cell death and importantly it is not always possible. Our work has shown that pharmacological intervention using either acetyl-L-carnitine (ALCAR) or N-acetyl-cysteine (NAC) give complete neuroprotection in different types of peripheral nerve injury. Both compounds are clinically safe and experimental work has defined the best dose, timing after injury and duration of administration. The efficacy of neuroprotection of ALCAR and NAC can be monitored non-invasively using MRI, as demonstrated experimentally and more recently by clinical studies of the volume of dorsal root ganglia. Translation to patients of this pharmacological intervention requires further work, but the available results indicate that this approach will help to secure a better functional outcome following peripheral nerve injury and repair.

\section{PeRIPHERAL NERVE INJURY AND NEURONAL CELL DEATH}

Peripheral nerve injury triggers a number of cellular and molecular events which can be fundamental for successful nerve regeneration following nerve repair. Distal to the injury, the process known as Wallerian degeneration is responsible for the dying out of the distal axons and the de-differentiation of Schwann cells. These proliferate and secrete a number of growth factors which have tropic and trophic effects on the regrowing axons $[1,2,3]$. However, a more important and often neglected aspect is the effect of the injury on the neuronal cells. It is now accepted that various factors influence the survival of neuronal cells following peripheral nerve injury, with sensory neurons in dorsal root ganglia more susceptible to cell death following distal nerve injury $[3,4,5]$ while spinal motoneurons die only after proximal injury $[1,3,6]$.

\subsection{Sensory neurons cell death}

Following distal nerve injury and nerve repair, limited motor function restoration, due to survival of motoneurons, can compensate 
for poor axonal regeneration of sensory motoneurons, but sensory recovery is affected more substantially as the innervation density of target organs is critical for restoration of sensory function $[7,8,9]$. There is no doubt that that neuronal cell death contributes to poor functional recovery following nerve repair, in particular when surgical repair is delayed post-injury. Sensory neuronal cell death starts soon after nerve axotomy. Experimentally it has been shown that a statistically significant cell loss is already evident in the dorsal root ganglia at one week post-injury if repair is not carried out $[10,11,12]$. Loss of sensory neurons increases with time reaching a value of $35-40 \%$ of the total neuronal cell population in the dorsal root ganglia at 2 months post-injury [11]. Sensory cell loss varies considerably according to the level of injury along the nerve, with more proximal injury provoking a wider neuronal cell death [13].

These experimental results have been validated in one human post-mortem study [14], where the magnitude of neuronal cell loss appears to correspond to the loss of functional sensory recovery after nerve repair [15]. Although motoneurons survive a distal nerve injury, approximately $30 \%$ of motoneurons die after spinal nerve injury, and $50 \%$ or more after experimental ventral rhizotomy or root avulsion [5, $6,16]$. As neuronal cells cannot be replaced after death, it is inevitable that regeneration will be poor, with significant loss of sensory and motor functions $[7,9,17,18]$.

Interestingly, cutaneous sensory afferent neurons appear to be more susceptible to cell death than sensory motor afferents [4, 19, 20]. In particular small diameter cutaneous afferent neurons undergo cell death more easily than large diameter cutaneous afferent ones, although there are no clear links to quality of sensation after nerve regeneration. This difference is more likely to be due to the dependence of the small sensory neurons on neurotrophins, such as NGF, BDNF, NT-3 and NT-4, as following injury there is a loss of neutrophic support derived from the target organs $[1,3,21]$. The regenerative potential of both cutaneous and muscular afferent neurons is dependent on the activation of peripherin and ATF3 gene expression, while those neurons lacking regeneration have a significant lower expression of these genes [22]. After injury there is activation of both regenerative and cell death signalling in any type of neuron, and it is the balance between the two that determines whether the neuronal cell will survive and regenerate or die [23]. 


\subsection{Signalling pathways of neuronal cell death}

This equilibrium is probably due to various intrinsic and extrinsic cellular signalling pathways, and our experiments have indicated that the balance between intracellular pro-apoptotic and pro-survival signalling determines the fate of the cell. Neuronal cell death is regulated by an apoptosis pathway, and regulating this pathways are the pro-survival mediator $\mathrm{Bcl}-2$ and the pro-apoptotic $\mathrm{Bax}$, which interact at the mitochondrial level determining their membrane permeabilization [24, 25, 26]. The predominance of Bax signalling leads to the formation of pores in the mitochondrial membrane, allowing the release of cytochrome $\mathrm{C}$ and other apoptotic molecules that cause activation of the caspase cascade [27], and in particular of caspase- 3 which exerts a death-inducing action on cells $[28,29]$. Following differential nerve axotomy of medial gastrocnemius nerve or sural nerve, gene analysis was carried out on the corresponding sensory neurons, which have been previously shown respectively to survive or die following nerve injury [20]. Interestingly, the survival of the muscle afferent sensory neurons of the gastrocnemius nerve corresponded to a significant upregulation of the pro-survival Bcl-2 gene and downregulation of Bax and caspase- 3 , while in the cutaneous sensory afferent neurons there is an upregulation of the pro-apoptotic Bax and caspase-3 gene expression, which is the likely cause of their death [30].

It is evident from all these studies that neuronal cell death is a significant and common occurrence after nerve injury, which if not addressed would results in deficient axonal regeneration and loss of functional recuperation. Neuronal survival is essential for regeneration [1], and immediate nerve repair after injury reduces loss of both sensory and motor neurons $[11,31]$. Although early repair is recommended where appropriate, it is recognized that this surgical strategy is not always applicable [32], and a pharmacological approach to neuroprotection is therefore essential.

\section{Pharmacological NeURoprotective Strategies}

Neuroprotective intervention has been studied widely for the central nervous system [33, 34], but very little has been reported for the peripheral nervous system, and it is generally related to the administra- 
tion of neurotrophic factors [3, 35]. However, this latter approach has limited clinical relevance as different neuronal sub-populations respond specifically to the administration of different neurotrophic factors, hence the need to use different mixtures of growth factors for each type of nerve. Furthermore, side effects of such treatments have discouraged their clinical application [36,37]. More recently, two pharmacological agents, acetyl-L-carnitine (ALCAR) and N-acetyl-cysteine (NAC), have been shown to have the requisite neuroprotective potential, possibly due to their antioxidant effect, and both are established as safe clinical pharmaceutical agents [38].

\subsection{ALCAR}

Systemic administration of ALCAR after experimental sciatic nerve injury without repair reduces significantly neuronal cell loss in dorsal root ganglia, and this neuroprotective effect is maintained up to 2 months post-injury [39]. A dose response study has established an optimal dose of $50 \mathrm{mg} / \mathrm{kg} /$ day [40], and a delayed administration of 24 hours post-injury still has efficacy in preventing neuronal cell loss [41], another important point for the future clinical translation of this treatment. Interestingly, ALCAR administration promotes nerve regeneration separately from its neuroprotective effect [42] with increased target organ reinnervation [43]. Unfortunately, ALCAR does not have a neuroprotective effect on motoneurons, which would limit its applicability only to distal nerve injury.

\section{$2.2 N A C$}

A neuroprotective effect has also been demonstrated for NAC in both sensory [44] and motor neurons [16]. Systemic administration of $150 \mathrm{mg} / \mathrm{kg} /$ day was optimal for sensory neuronal survival after experimental sciatic nerve injury [45], and a treatment duration of 4 weeks reduces the cell loss to only $5 \%$, with total neuroprotection if the NAC is administered for 8 weeks post-injury (unpublished). A higher dose of $750 \mathrm{mg} / \mathrm{kg} /$ day was more effective for motoneuron survival after ventral rhizotomy [16], but importantly there was no loss of neuroprotective effect if the administration of NAC was delayed for 1 week after root avulsion [16]. The anti-apoptotic effect of NAC administration was demonstrated by the preservation of the mitochondria structure in sen- 
sory neurons following nerve injury [44], which is consistent with the marked downregulation of the pro-apoptotic genes Bax and caspase-3 in cutaneous sensory afferent neurons following sural nerve injury and NAC administration [30], confirming the neuroprotective properties of this compound.

\subsection{Clinical application}

The problem faced by the clinician in applying these neuroprotective strategies is how to define the success of the treatment. In the experimental studies described above the dorsal root ganglia and spinal cord are harvested from the animal at the end of the experiments, and neuronal counts are carried out on with stereological techniques [46]. However, it was shown that the neuronal loss observed after nerve transection is correlated with the volume of the axotomized dorsal root ganglia [11]. In the past, magnetic resonance imaging (MRI) has provided a non-invasive assessment of rodent peripheral nervous system structures $[47,48]$, and in our experience it has been useful to determine the volume of dorsal root ganglia as a proxy measure of neuronal cells death or survival. Following rat sciatic nerve axotomy, we have compared morphological measurement of sensory ganglia volume and neuronal cells death with calculation of volume carried out on MRI images. There is a strong correlation between the morphological and MRI results, with the MRI volume of the dorsal root ganglia being a representative measure of the number of neurons in the ganglia [49].

Hence, it appears that MRI volumetric quantification of dorsal root ganglia can be developed clinically as a non-invasive measure of sensory neuronal survival after ALCAR or NAC treatment. As a precursor to such a clinical trial, we have carried out morphological assessment of numbers of sensory neurons and ganglia volume on cadavers and compared them with the ganglia volume of healthy volunteers, and of patients that have suffered arm amputations and median/ulnar nerve injuries [50]. Using cadaver ganglia, we have shown that there was low inter-individual variability in DRG neuronal counts and volume, and strong correlation between counts and MRI volume measurements. MRI also gives good resolution for volumetric analysis in patients, confirming the validity of proxy measurement of sensory neurons in human, but further clinical studies are necessary to determine the sensitivity for the MRI technique used following different nerve injuries at different times. 


\section{CONCLUSIONS}

The functional outcome of peripheral nerve injury remains inadequate despite the technical advances of microsurgical nerve repair. The understanding of the cellular and molecular mechanisms underlying the neuronal response to nerve injury have indicated that a combined surgical and neuroprotective approach could give the best results. The work presented here shows that pharmacological intervention can be used to prevent neuronal cells death, and that the efficacy of the treatment can be assessed non-invasively.

Although initially these drugs should not be given outside the framework of an appropriate clinical trial, with a specific and sensitive outcome measure, there is little doubt that in future such applications will result in an improved functional outcome for the patients allowing them to return to a better work and social lives.

\section{REFERENCES}

1. Fu SY, Gordon T. The cellular and molecular basis of peripheral nerve regeneration. Mol Neurobiol. 1997, 14: 67-116.

2. Hall S. Nerve repair: A neurobiologist view. J Hand Surg Br. 2001, 26: 129-136.

3. Terenghi G. Peripheral nerve regeneration and neurotrophic factors. J Anat. 1999, 194: 1-14.

4. Hu P, McLachlan EM. Selective reactions to cutaneous and muscle afferent neurons to peripheral nerve transaction in rats. J Neurosci. 2003, 23: 10559-10567.

5. Ma J, Novikov LN, Wiberg M, Kellerth JO, Novikov LN. Delayed loss of spinal motoneurons after peripheral nerve injury in adult rats: A quantitative morphological study. Exp Brain Res. 2001, 139: 216-223.

6. Gu Y, Spasic Z, Wu W. The effects of remaining axons on motoneurons survival and NOS expression following axotomy in the adult rat. Dev Neurosci. 1997, 19: 255-259.

7. Shenker M, Burstedt MK, Wiberg M, Johanson RS. Precision grip function after hand replantation and digital nerve injury. J Plast Reconstr Aesthet Surg. 2006, 59: 706-716.

8. Westling G, Johansson RS. Factors influencing the force control during precision grip. Exp Brain Res. 1984, 53: 277-284.

9. Wiberg M, Hazari A, Ljungberg C, Pettersson K, Backman C, Nordh E, KvastRabben O, Terenghi G. Sensory recovery after hand reimplantation: A clinical, morphological and neurophysiological study in human. Scand J Plast Reconstr Surg Hand Surg. 2003, 37: 163-173. 
10. Groves MJ, Christopherson T, Giometto B, Scaravilli F. Axotomy-induced apoptosis in adult rat primary sensory neurons. J Neurocytol. 1997, 26: 615-624.

11. McKay Hart A, Brannstrom T, Wiberg M, Terenghi G. Primary sensory neurons and satellite cells after peripheral axotomy in the adult rat: Timecourse of cell death and elimination. Exp Brain Res. 2002, 142: 308-318.

12. Vestergaard S, Tandrup T, Jakobsen J. Effect of permanent axotomy on number and volume of dorsal root ganglion cell bodies. J Comp Neurol. 1997, 388: 307-312.

13. Ygge J. Neuronal loss in lumbar dorsal root ganglia after proximal compared to distal sciatic nerve resection: A quantitative study in the rat. Brain Res. 1989, 478: 193-195.

14. Suzuki H, Oyanagi K, Takahashi H, Kono M. A quantitative pathological investigation of the cervical cord, roots and ganglia after long-term amputation of the unilateral upper arm. Acta Neuropathol. 1993, 85: 666-673.

15. Kuyper PD, van Egeraat JM, Godschalk M , Hovius SER. Loss of viable neuronal units in the proximal stump as possible cause for poor function recovery following nerve reconstruction. Exp Neurol. 1995, 132: 77-81.

16. Zhang CG, Welin D, Novikov LN, Kellerth JO, Wiberg M, Hart AM. Motoneuron protection by $\mathrm{N}$-acetyl-cysteine after ventral root avulsion and ventral rhizotomy. Br J Plast Surg. 2005, 58: 765-773.

17. Allan CH. Functional results of primary nerve repair. Hand Clin. 2000, 16: 67-72.

18. Kelly EJ, Terenghi G, Hazari A, Wiberg M. Nerve fibre and sensory end organ density in the epidermis and papillary dermis of the human hand. Br J Plast Surg. 2005, 58: 774-779.

19. Tandrup T, Woolf CJ, Coggleshall RE. Delayed loss of small dorsal root ganglion cells after transaction of the rat sciatic nerve. J Comp Neurol. 2000, 422: 172-180.

20. Welin D, Novikova LN, Wiberg M, Kllerth JO, Novikov LN. Survival and regeneration of cutaneous and muscular afferent neurons after peripheral nerve injury in adult rats. Exp Brain Res. 2008, 186: 315-323.

21. Ambron RT, Walters ET. Primary events and retrograde injury signals. A new perspective on the cellular and molecular biology of nerve regeneration. Mol Neurobiol. 1996, 13: 61-79.

22. Reid AJ, Welin D, Wiberg M, Terenghi G, Novikov LN. Peripherin and ATF3 genes are differentially regulated in regenerating and non-regenerating primary sensory neurons. Brain Res. 2010, 1310: 1-7.

23. Nunez G, del Peso L. Linking extracellular survival signal and the apoptotic machinery. Curr Opin Neurobiol. 1998, 8: 613-618.

24. Adams JM, Cory S. Bcl-2 regulated apoptosis: Mechanism and therapeutic potential. Curr Opin Immunol. 2007, 19: 488-496.

25. Gillardon F, Klimaschewski L, Wickert H, Krajewski S, Reed JC, Zimmerman M. Expression pattern of candidate cell death effector protein Bax, Bcl2, BclX and c-Jun in sensory and motor neurons following sciatic nerve transaction in the rat. Brain Res. 1996, 739: 244-250.

26. Korsmeyer SJ, Shutter JR, Veis DJ, Merry DE, Oltvai ZN. Bcl-2/Bax: A rheostat 
that regulates an anti-oxidant pathway and cell death. Semin Cancer Biol. 1993, 4: 327-332.

27. Benn SC, Woolf CJ. Adult neuron survival strategies - slamming on the brakes. Nat Rev Neurosci. 2004, 5: 686-700.

28. Janicke RU, Sprengart ML, Wati MR, Porter AG. Caspase-3 is required for DNA fragmentation and morphological changes associated with apoptosis. J Biol Chem. 1998, 273: 9357-9360.

29. Putcha GV, Johnson EM Jr. Men are but worm: neuronal cell death in C elegans and vertebrates. Cell Death Differ. 2004, 11:38-48.

30. Reid AJ, Shawcross SG, Hamilton AE, Wiberg M, Terenghi G. N-acetyl-cysteine alters apoptotic gene expression in axotomised primary sensory afferent subpopulation. Neurosci Res. 2009, 65: 148-155.

31. Ma J, Novikov LN, Kellerth JO, Wiberg M. Early nerve repair after injury to the postganglionic plexus: An experimental study of sensory and motor neuronal survival in adult rats. Scand J Plast Reconstr Surg Hand Surg. 2003, 37: 1-9.

32. Birch R. Surgical disorders of the peripheral nerve, 2nd Edn., Springer-Verlag, London 2011.

33. Baptiste DC, Fehlings MG. Update on the treatment of spinal cord injury. Prog Brain Res. 2007, 161: 217-233.

34. Faden AI, Stoica B. Neuroprotection: Challenges and opportunities. Arch Neurol. 2007, 64: 794-800.

35. Lundborg G. A 25-year perspective of peripheral nerve surgery: Evolving neuroscientific concepts and clinical significance. J Hand Surg Am. 2000, 25: 391-414.

36. Martin D, Merkel E, Tucker KK. Cachectic effect of ciliary neurotrophic factor on innervated skeletal muscle. Am J Physiol. 1996, 271: 1422-1428.

37. Metcalf D, Gearing DP. Fatal syndrome in mice engrafted with cells producing high levels of leukemia inhibitory factor. Proc Natl Acad Sci USA. 1989, 86: 5948-5952.

38. Hart AM, Wilson AD, Mantovani C, Smith C, Johnson M, Terenghi G, Youle M. Acetyl-carnitine: A pathogenesis based treatment for HIV-associated antiretroviral toxic neuropathy. AIDS. 2004, 18: 1549-1560.

39. Hart AM, Wiberg M, Youle M, Terenghi G. Systemic acetyl-L-carnitine eliminates sensory neuronal loss after peripheral axotomy: A new clinical approach to the management of peripheral nerve trauma. Exp Brain Res. 2002, 145: 182-189.

40. Wilson AD, Hart AM, Brannstrom T, Wiberg M, Terenghi G. Primary sensory neuronal rescue with systemic acetyl-L-carnitine following peripheral axotomy. A dose-response analysis. Br J Plast Surg. 2003, 56: 732-739.

41. Wilson AD, Hart AM, Brannstrom T, Wiberg M, Terenghi G. Delayed acetyl-Lcarnitine administration and its effect on sensory neuronal rescue after peripheral nerve injury. J Plast Reconstr Aesthet Surg. 2007, 60: 114-118.

42. Hart AM, Wiberg M, Terenghi G. Pharmachological enhancement of peripheral nerve regeneration by systemic acetyl-L-carnitine treatment. Neurosci Lett. 2002, 334: 181-185.

43. Wilson AD, Hart AM, Wiberg M, Wiberg M. Acetyl-L-carnitine increases nerve 
regeneration and target organ reinnervation. A morphological study. J Plast Reconstr Aesthet Surg. 2010, 63: 1186-1195.

44. Hart AM, Terenghi G, Kellerth JO, Wiberg M. Sensory neuroprotection, mitochondrial preservation and therapeutic potential of $\mathrm{N}$-acetyl-cysteine after nerve injury. Neurosci. 2004, 125: 91-101.

45. West CA, Hart AM, Terenghi G, Wiberg M. Analysis of the dose-response of Nacetyl-cysteine in the prevention of sensory neuronal loss after peripheral nerve injury. Acta Neurochir Suppl. 2007, 100: 29-31.

46. Hart AM, Terenghi G. Frozen section fluorescence microscopy and stereology in the quantification of neuronal death within dorsal root ganglia. J Mol Histol. 2004, 35: 565-580.

47. Aagaard BD, Lazar DA, Lankerovich L, Andrus K, Hayes CE, Maravilla K, Kliot M. High resolution magnetic resonance imaging is a non-invasive method of observing injury and recovery in the peripheral nervous system. Neurosurg. 2003, 53: 199-203.

48. Bjorn B, Schnabel R, Mirastschijski U, Ibrahim B, Angenstein F, Schneider W. Magnetic resonance imaging monitoring of peripheral nerve regeneration following neurotmesis at 4.7 Tesla. Plast Reconstr Surg. 2009, 123: 1778-88.

49. West CA, Davies KA, Hart AM, Wiberg M, Williams SR, Terenghi G. Volumetric magnetic resonance imaging of dorsal root ganglia for the objective quantitative assessment of neuron death after peripheral nerve injury. Exp Neurol. 2007, 203: 22-33.

50. West CA, Hart AM, Terenghi G, Wiberg M. Sensory neurons of the human brachial plexus: A quantitative study employing optical fractionation and in vivo volumetric magnetic resonance imaging. Neurosurg. 2012, 70: 1183-1194. 